NBER WORKING PAPER SERIES

\title{
HOW SHOULD WE MEASURE CONSUMER CONFIDENCE (SENTIMENT)? EVIDENCE FROM THE MICHIGAN SURVEY OF CONSUMERS
}

\author{
Jeff Dominitz \\ Charles F. Manski \\ Working Paper 9926 \\ http://www.nber.org/papers/w9926
}

NATIONAL BUREAU OF ECONOMIC RESEARCH
1050 Massachusetts Avenue
Cambridge, MA 02138

August 2003

This research was supported in part by National Institute on Aging grant 2 P01 AG10179-04A1 and by a grant from the Searle Fund. We are grateful to the University of Michigan Survey Research Center's Committee for Research Initiatives in the Monthly Survey, which approved placement of the "percent chance" questions on the Survey of Consumers. We are also grateful to Richard Curtin, Principal Investigator of the Survey of Consumers, for his cooperation in this endeavor. The views expressed herein are those of the authors and not necessarily those of the National Bureau of Economic Research.

(C2003 by Jeff Dominitz and Charles F. Manski. All rights reserved. Short sections of text, not to exceed two paragraphs, may be quoted without explicit permission provided that full credit, including (C) notice, is given to the source. 
How Should We Measure Consumer Confidence (Sentiment)? Evidence from the Michigan Survey of Consumers Jeff Dominitz and Charles F. Manski

NBER Working Paper No. 9926

August 2003

JEL No. D1, D8, E2

\begin{abstract}
The Michigan Index of Consumer Sentiment (ICS) and other indices of consumer confidence are prominent in public discourse on the economy but have little presence in modern economic research. The sparsity of modern research follows an earlier period when economists scrutinized in some depth the methods and data used to produce consumer confidence indices. The literature to date has focused on the predictive power of the survey data used to form the indices; there has been very little study of their micro foundations. This paper analyzes the responses to eight expectations questions that have appeared on the Michigan Survey of Consumers in the period June 2002 through May 2003. Four questions elicit micro and macroeconomic expectations in the traditional qualitative manner; two are components of the ICS. Four questions use a "percent chance" format to elicit subjective probabilities of micro and macroeconomic events; versions of these questions have previously appeared in the Survey of Economic Expectations.
\end{abstract}

\author{
Jeff Dominitz \\ H. John Heinz III School of Public Policy and Management \\ Carnegie Mellon University \\ 5000 Forbes Avenue \\ Pittsburgh, PA 15213 \\ dominitz@andrew.cmu.edu \\ Charles F. Manski \\ Department of Economics \\ Northwestern University \\ 2001 Sheridan Road \\ Evanston, IL 60208 \\ and NBER \\ cfmanski@northwestern.edu
}




\section{$\underline{1 . \text { Introduction }}$}

In April 2001, concern about the state of the U. S. economy was evident in a New York Times headline declaring "Confidence of Consumers at 8-year Low" and in an Economist story reporting that "Consumer confidence is now down to the same level as when America went into recession in 1990." Two years later, in February 2003, Reuters reported "Consumer Sentiment Hits 9-Year Low." The Times, Economist, and Reuters reports stated that their conclusions were based on an index issued monthly by the University of Michigan, but did not describe the index. Apparently, the meaning and measurement of consumer confidence were considered sufficiently well known as not to require explanation. Indeed, the Michigan Index of Consumer Sentiment is reported regularly in the media, along with commentary on its significance for the economy. So is another one, the Consumer Confidence Index issued monthly by the Conference Board.

The Michigan index was developed a half-century ago by George Katona and colleagues at the Survey Research Center of the University of Michigan (see Curtin, 1982). The Conference Board index has been issued since 1967 (see Linden, 1982). Both indices aggregate survey responses to a set of questions about current and expected economic conditions. The Michigan index is described in Appendix A, which is taken from the code book of the Michigan Survey of Consumers. The Conference Board appears not to make public its specific questions.

Notwithstanding their prominence in public discussions of the economy, the Michigan and Conference Board indices have little presence in modern economic research. Neither consumer confidence nor consumer sentiment appears in the Journal of Economic Literature Subject Index of

\footnotetext{
${ }^{1}$ David Leonhardt, the New York Times, Business Section, April 13, 2001; The Economist, April 21, 2001, page 23; Reuters, February 28, 2003, 10:32 AM.
} 
Journal Articles. A search for the two terms in EconLit revealed 78 occurrences in the abstracts of articles and discussion papers published from 1969 through February 2003, but relatively few of these were in "mainstream" economics journals. The research that has been performed has mainly sought to evaluate the predictive power of the Michigan and Conference Board indices in forecasting aggregate consumption and other macroeconomic variables.

The sparsity of modern research follows an earlier period when economists scrutinized in some depth the methods and data used to produce consumer confidence indices. In the 1940 s, the U.S. Federal Reserve Board began to fund an annual Survey of Consumer Finances, conducted by the University of Michigan Survey Research Center (SRC), that posed qualitative questions of the type used to form the Index of Consumer Sentiment. The usefulness of such questions was controversial and the Federal Reserve Board appointed a committee to assess their value. The Federal Reserve Consultant Committee on Consumer Survey Statistics (1955), known informally as the Smithies Committee for its chair Arthur Smithies, issued findings that questioned the predictive power of the SRC data. The negative findings of the Committee were challenged by SRC researchers, notably Katona (1957). A contentious conference followed (National Bureau of Economic Research, 1960). Then Juster (1964) reported an intensive study, drawing largely negative conclusions, on the predictive usefulness of qualitative approaches to elicitation of consumer expectations. By the mid-1960s, opinion among mainstream economists was firmly negative. However, SRC continued to perform its consumer surveys and to publish aggregated findings in its Index of Consumer Sentiment. 
Economists today may be inclined to regard the prominence of consumer confidence indices in public discussions of the economy as no more than an illustration of how little the public understands serious economic research. However, there should be more to it than that. Economists who study the decision making of consumers, firms, and governments should want to learn how these agents use publicly available economic information. We should, moreover, want to improve the quality of such public information. For these reasons, economists should examine the production and utilization of consumer confidence indices. Going further, we should endeavor to develop measures that improve on the ones now available.

Various types of research can shed light on these matters, in differing respects. The literature to date has focused on the predictive power of the data used to form consumer confidence indices. The Smithies Committee, as well as Tobin (1959) and Juster (1964), recommended that predictive power be evaluated by the ability of individual survey responses to predict subsequent individual outcomes (e.g., durable goods expenditures) reported later in re-interviews. However, Katona (1957) and Mueller (1957) argued that aggregate predictive tests are equally relevant. Recent studies have used aggregate time series data to perform macro predictive tests broadly of the form advocated by Katona and Mueller. The standard practice has been to regress an outcome of interest on a consumer confidence index and other economic indicators. The value of the index is then measured by its estimated coefficient in the regression, statistical significance, or contribution to $\mathrm{R}^{2}$. See, for example, Batchelor and Dua (1998), Carroll, Fuhrer, and Wilcox (1994), Fuhrer (1988), Kumar, Leone, and Gaskins (1995), Madsen and McAleer (2000), and Matsusaka and Sbordone (1995).

Although aggregate predictive tests may be useful, we believe that the Smithies Committee 
was correct to recommend study of the micro foundations of consumer confidence indices. Examination of the wording of the Michigan questions indicates inherent weaknesses that we have found commonplace in attitudinal research (see Manski, 1990; Dominitz and Manski, 1997a, 1997b, 1999; Das, Dominitz, and van Soest; 1999). One obvious problem is that the events about which respondents are queried are remarkably vague. Another is that the expectations questions posed do not permit respondents to express uncertainty. Consider, for example, the question:

"Now looking ahead - do you think that a year from now you (and your family living there) will be better off financially, or worse off, or just about the same as now?"

How do respondents interpret the phrase "better off financially?" Do different respondents interpret the phrase in the same way? How do respondents who are uncertain of their future prospects answer the question? We believe that empirical research addressing these and related issues is essential if we are to understand the Michigan index and improve on it. This paper presents such research.

The data analyzed here are responses to eight expectations questions that have appeared on the Survey of Consumers in the period June 2002 through May 2003. Four questions elicit micro and macroeconomic expectations in the traditional qualitative manner, and two of these questions are components of the Index of Consumer Sentiment. The other four questions use a "percent chance" format to elicit subjective probabilities of micro and macroeconomic events; versions of these questions have previously appeared in our own Survey of Economic Expectations (Dominitz and Manski, 1997a, 1997b).

Section 2 describes the expectations data collected in the Survey of Consumers. In Section 3, we examine month-to-month temporal fluctuations in the central tendency of these expectations. Section 4 analyzes the cross-sectional variation of expectations with personal attributes. Section 5 
uses re-interviews of respondents to study the temporal stability and variability of individual expectations. Drawing lessons from the findings, Section 6 concludes with a set of questions regarding effective conceptualization and measurement of consumer confidence.

\section{Measures of Expectations in the Survey of Consumers}

\subsection{The Index of Consumer Sentiment (ICS)}

As documented in Appendix A, the ICS is currently constructed based on responses to five questions asked in the Survey of Consumers. These five questions concern two assessments of current outcomes - family finances and "buying conditions"-and three assessments of future outcomes - family finances in the year ahead, business conditions in the year ahead, and aggregate economic conditions over the next five years. When the Survey of Consumers was initiated in the early 1950s, responses to a price expectations questions were also included in what was referred to as the "index of consumer attitudes" (Mueller, 1957). Approximately four years into this Survey Research Center program, one of the principal investigators stated, "Tentatively, the six components of the index have been given equal weight” (Mueller, 1957, p. 949). The remaining five components are still given equal weight.

The ICS is constructed as follows: For each question, the relative score is calculated as (a) the difference between the percentage of respondents giving "favorable" responses and the percentage giving "unfavorable" responses plus (b) the value 100. Then, the ICS equals (a) the sum 
of the five relative scores divided by 6.7558 (the sum of the relative scores in 1966) plus (b) a constant to "correct for" changes in sample design over the history of the survey.

\subsection{Qualitative and Quantitative Expectations Questions}

The four longstanding Michigan qualitative expectations questions whose responses we study are listed in Appendix B. These questions, each of which has a 12-month forecast horizon, concern expectations of the change in family finances (PEXP), family income (INEXQ1), and national business conditions (BEXP), as well as expectations of the level (e.g., "good" or "bad") of business conditions (BUS12). With the exception of BUS12, these questions have three response options, exemplified by the question on family finances discussed in the introduction. Throughout this paper we analyze BUS12 as a three-response question as well. To do so, we aggregate the "good" and "qualified good" responses, and likewise aggregate the "bad" and "qualified bad" responses.

Six "percent chance" questions have been asked in the Michigan survey since June 2002. These questions are listed in Appendix C. These questions have been designed to elicit interpersonally comparable expectations of well-defined events. Importantly, the questions elicit expectations in the form called for by modern economic theory; that is, in the form of subjective probabilities.

One may contrast the qualitative assessments in the Michigan questions with, for example, the following probabilistic assessment of personal income (V252):

"What do you think is the percent chance that your income in the next twelve months will be 
higher than your income in the past twelve months?"

We analyze responses to question V252 and three other probabilistic questions with one-year forecast horizons. These questions concern the chance that a mutual fund investment will increase in value (V250), the chance that the respondent will lose his or her job (V255), and, conditional on the loss of this job, the chance the respondent would find and accept an "equally good job" (V256).

With the exception of the mutual fund question, these questions have been asked in the Survey of Economic Expectations (SEE) since 1994. We discuss the origins of these SEE questions in Dominitz and Manski (1997a, 1997b). A set of mutual fund expectations questions, similar to those asked in the Michigan survey, were asked in SEE from 1999 through 2001. Responses to these questions, discussed in Section 3, have not previously been analyzed. ${ }^{2}$

\subsection{Surveys of Consumers: June 2002 - May 2003}

Each month, the Survey of Consumers is completed by telephone by approximately 500 adult men and women who live in the coterminous United States. Michigan has adopted a rotating panel design for this survey, in which the majority of individuals (approximately 60\%) are first time respondents from whom re-interviews will be attempted six months thereafter. Thus, over the 12month period of our analysis, we obtain data in each of the final six months from re-interviews of approximately 200 of the 300 individuals who were in the sample six months earlier and had not previously been interviewed. The following table describes the sample of respondents from June

\footnotetext{
${ }^{2}$ SEE respondents were asked to report the highest and lowest possible (one-year ahead) value for a $\$ 1000$ investment today in a mutual fund. These responses were then used to select a sequence of threshold values $\mathrm{X}$ for questions of this form: "What do you think is the percent chance (or chances out of 100) that, one year from now, this investment would be worth over \$X?" For each respondent, one such value was 1000, yielding a question equivalent to V250.
} 
2002 to May 2003:

\begin{tabular}{|c|c|c|c|c|}
\hline Month & $\begin{array}{c}\text { Total Number of } \\
\text { Respondents }\end{array}$ & $\begin{array}{c}\text { Number of Initial } \\
\text { Interviews }\end{array}$ & $\begin{array}{c}\text { Number of } \\
\text { Re-Interviews }\end{array}$ & $\begin{array}{c}\text { Re-Interview } \\
\text { Response Rate }\end{array}$ \\
\hline Jun-02 & 501 & 301 & 200 & --- \\
\hline Jul-02 & 501 & 300 & 201 & --- \\
\hline Aug-02 & 500 & 291 & 209 & --- \\
\hline Sep-02 & 501 & 300 & 201 & --- \\
\hline Oct-02 & 502 & 295 & 207 & --- \\
\hline Nov-02 & 504 & 304 & 200 & --- \\
\hline Dec-02 & 500 & 290 & 210 & 0.70 \\
\hline Jan-03 & 501 & 285 & 216 & 0.72 \\
\hline Feb-03 & 501 & 296 & 205 & 0.70 \\
\hline Mar-03 & 504 & 295 & 209 & 0.70 \\
\hline Apr-03 & 500 & 293 & 207 & 0.70 \\
\hline May-03 & 500 & 293 & 207 & 0.68 \\
\hline
\end{tabular}

Observe that the total sample varies only from 500 to 504 observations each month over this time period. The initial interviews each month are 12 independent random samples of size 285 to 304. The panel component of the survey yields a total sample size of 1254 individuals, with a reinterview response rate ranging from $68 \%$ (Nov-02 to May-03) to $72 \%$ (Jul-02 to Jan-03).

Calculation of the ICS includes responses given by both initial-interview and re-interview respondents. In Section 3, we follow this practice to describe temporal fluctuations of the distribution of expectations. However, in Section 4, where we describe the cross-sectional variation of expectations, we only use data from initial interviews to avoid double counting sample members. In Section 5, where we analyze temporal fluctuations of individual expectations, we restrict attention to those who completed both an initial interview during the period Jun-02 through Dec-02 and a reinterview during the period Jan-03 through May-03. 


\section{Temporal Fluctuations in the Distribution of Expectations}

The main use of the ICS has been to measure temporal fluctuations in consumer confidence. The index aggregates responses to disparate questions with ordinal response categories. Hence, there is no clear meaning to the magnitude of changes over time in the index. Indeed, even the direction of change in the ICS is not clearly interpretable if responses to the component questions move in different directions.

To obtain a clear sense of temporal fluctuations, we examine the month-to-month variation in responses to each question, one at a time. We also compare the responses to related qualitative and percent-chance questions. The empirical findings are reported in Tables 1 and 2.

\subsection{ICS Qualitative Expectations}

In a pattern that recurs throughout our analysis of qualitative expectations, Tables $1 \mathrm{~A}$ and $1 \mathrm{~B}$ show much greater month-to-month volatility in responses to the macroeconomic expectations question concerning national business conditions (BUS12) than to the personal expectations question concerning family finances (PEXP). We show below the range of frequencies (as a percentage of the sample) giving favorable or unfavorable responses, and the difference in these percentages plus 100 (i.e., the ICS relative score): 


\begin{tabular}{|c|c|c|c|c|c|}
\hline & & minimum & (month) & maximum & (month) \\
\hline \multirow[t]{3}{*}{ BUS12 } & $\%$ good & 26.6 & Feb-03 & 54.4 & May-03 \\
\hline & $\%$ bad & 34.7 & Jun-02 & 62.1 & Mar-03 \\
\hline & $\begin{array}{c}\% \text { good }-\% \text { bad } \\
+100\end{array}$ & 65.5 & Mar-03 & 118.4 & Мay-03 \\
\hline \multirow[t]{3}{*}{ PEXP } & $\%$ better & 37.9 & Jan-03 & 43.8 & May-03 \\
\hline & $\%$ worse & 5.6 & Jun-02 & 12.6 & Jan-03 \\
\hline & $\begin{array}{c}\% \text { better - } \% \text { worse } \\
+100\end{array}$ & 125.4 & Jan-03 & 137.1 & Jun-02 \\
\hline
\end{tabular}

Observe that the ICS relative score for BUS12 rises from a 12-month minimum of 65.5 in Mar-03 to a 12-month maximum of 118.4 in May- 03 , just two months later. In contrast, the ICS relative score for PEXP varies only between 125.4 and 137.1 during the entire 12-month period.

The greater time-series volatility of responses to question BUS12 could have several explanations. It could be that the macroeconomic and personal financial outcomes are equally variable, but that respondents are less informed about the economy than about personal finances and, hence, have expectations that fluctuate more over time. Or the economy may really be more volatile than are personal finances. Or, the volatility of responses to BUS12 may arise from the vagueness of the question wording, which asks whether "business conditions" are "good" or "bad."

We find greater nonresponse to BUS12 ( $9 \%$ overall) than to PEXP (3\% overall). We conjecture that individuals are less likely to respond when they are more uncertain about the appropriate response. Once again, greater uncertainty may occur because respondents are less well informed about the outcome, because the outcome actually is more volatile, or because the question 
wording is more difficult to interpret.

Regardless of the explanation, we find that variation in PEXP responses contributes little to fluctuation in the ICS over this time period, relative to variation in BUS12. Historical evidence shows that this is a longstanding feature of the ICS. The Survey of Consumers website (http://www.sca.isr.umich.edu/) makes available quarterly reports of the relative score for each component of the ICS since 1960. Over the past 42 years, the PEXP relative score varied from a minimum of 92 to a maximum of 141 , with a standard deviation of 9.9. The BUS12 relative score varied from 35 to 168 , with a standard deviation of 31.7 .

\subsection{Other Qualitative Expectations Questions}

We now consider responses to two other questions that may help identify the source of the greater fluctuation of BUS12 relative to PEXP. The Survey of Consumers asks another question about national business conditions, BEXP, that seeks a "better" versus "worse" response rather than the "good" versus "bad" response sought in BUS12. The wording of question BEXP thus eliminates one source of ambiguity in BUS12, although it retains the vague reference to "business conditions." The survey also asks another personal question, INEXQ1, that focuses on family income rather than finances in general. Questions BEXP and INEXQ1 do not suffer from as much vagueness in wording as do BUS12 and PEXP. Hence, their responses may be somewhat more interpretable.

Tables 1C and 1D report the monthly frequencies. We find these peaks and troughs: 


\begin{tabular}{|c|c|c|c|c|c|}
\hline & & minimum & (month) & maximum & (month) \\
\hline \multirow[t]{3}{*}{ BEXP } & $\%$ better & 28.3 & Jan-03 & 45.2 & May-03 \\
\hline & $\%$ worse & 12.4 & Jun-02 & 26.2 & Mar-03 \\
\hline & $\begin{array}{c}\% \text { better - } \% \text { worse } \\
+100\end{array}$ & 102.8 & Jan-03 & 132.2 & Мay-03 \\
\hline \multirow[t]{3}{*}{ INEXQ1 } & $\%$ higher & 58.8 & $\begin{array}{l}\text { Apr/May- } \\
03\end{array}$ & 63.5 & Sep-02 \\
\hline & $\%$ lower & 12.0 & Sep-02 & 17.0 & Jan-03 \\
\hline & $\begin{array}{c}\% \text { higher }-\% \text { lower } \\
+100\end{array}$ & 142.7 & Jan-03 & 151.5 & Sep-02 \\
\hline
\end{tabular}

Nonresponse for BEXP is $2 \%$ overall, and for INEXQ1 is $1 \%$ overall.

These results indicate again that expectations for national business conditions are more volatile than are those for personal outcomes. However, the "better/worse" responses to question BEXP are considerably less volatile than are the "good/bad" responses to question BUS12. This reduction in volatility and in nonresponse suggests either that vague question wording is an important source of the fluctuations or that beliefs about the level of economic activity are more volatile than are beliefs about changes in the level of activity. Noting that nonresponse to question BEXP is much less common than to question BUS12, we conjecture that ambiguous wording is the primary explanation for the greater volatility of responses to the latter question.

Now consider the two questions asking about personal events, either family income or finances. The responses to questions INEXQ1 and PEXP exhibit much less time-series variation than do the responses to BUS12 and BEXP; the minimum and maximum values of the relative score for INEXQ1 (PEXP) vary by only 8.8 (11.7) points during the 12-month period. This indicates that expectations for national business conditions actually are more volatile than are expectations for 
personal finances.

\subsection{Probabilistic Investment and Income Expectations}

Unlike the qualitative questions, the "percent chance" questions concern relatively wellspecified events and have consistent wording across these events. The present discussion focuses on questions V250 and V252, which are most comparable to the Michigan qualitative questions. Question V250 elicits expectations of a macroeconomic event relevant to many consumers, the returns to a mutual fund investment, whereas V252 elicits expectations of personal income growth. The monthly distributions of responses to these questions are reported in Tables $1 \mathrm{E}$ and $1 \mathrm{~F}$ respectively.

We do not find the strong disparity in volatility that is evident in the responses to the qualitative questions. The mean likelihood of a positive return to a mutual fund investment ranges from a 39.3 percent chance in Oct-02 to 45.3 in Jun-02. The mean likelihood of an increase in personal income ranges from a 47.9 percent chance in May-03 to 54.2 in Dec-02. The median chance of mutual fund growth varies from 40 to 50 percent over the 12-month period, whereas the median chance of personal income growth remains constant at 50 percent each month.

We do find more nonresponse to question V250 (8.0\% overall) than to V252 (4\% overall). We conjecture that respondents are less informed about the stock market than about personal income and, hence, less likely to respond. 
Investment Expectations in the Survey of Economic Expectations

The mutual fund question V250 has previously been asked on three waves of the SEE survey conducted in the period 1999-2001, also by telephone with a national sample of respondents. We summarize the findings here:

\begin{tabular}{|c|c|c|c|c|c|c|c|}
\hline \multirow[b]{2}{*}{ months } & \multirow[b]{2}{*}{$\mathrm{N}$ (respondents) } & \multirow[b]{2}{*}{ mean } & \multirow[b]{2}{*}{ std dev } & \multicolumn{3}{|c|}{ Quantiles } & \multirow{2}{*}{$\begin{array}{c}\mathrm{N} \\
\text { (non- } \\
\text { respondents) }\end{array}$} \\
\hline & & & & 0.25 & 0.50 & 0.75 & \\
\hline $\begin{array}{l}\text { Jul-99 - } \\
\text { Nov-99 }\end{array}$ & 405 & 66.4 & 29.3 & 50 & 75 & 90 & 142 \\
\hline $\begin{array}{c}\text { Feb-00 - } \\
\text { May-00 }\end{array}$ & 335 & 70.8 & 27.2 & 50 & 75 & 95 & 130 \\
\hline $\begin{array}{c}\text { Sep-00 - } \\
\text { Mar-01 }\end{array}$ & 468 & 66.1 & 27.6 & 50 & 75 & 90 & 171 \\
\hline All & 1208 & 67.5 & 28.1 & 50 & 75 & 90 & 443 \\
\hline
\end{tabular}

Comparison of these results with those in Table $1 \mathrm{E}$ indicates that investment expectations in the period Jun-02 to May-03 are sharply lower than they were in the earlier period Jul-99 to Mar-01. However, this comparison should be made with caution. The nonresponse rate to the SEE question was $27 \%$, considerably higher than the $8 \%$ experienced when the same question has been administered on the Survey of Consumers. ${ }^{3}$

\section{Investment Expectations and the S\&P500}

Figure 1 plots the monthly mean percent chance of mutual fund growth reported in the Survey of Consumers against the daily time series of the Standard and Poors 500 (S\&P). The two

\footnotetext{
${ }^{3}$ The variation in response rates is due at least in part to the questionnaire design. As explained in footnote 2, SEE respondents were first asked to state the minimum and maximum values they believe the investment may have a year after the interview. Respondents who did not answer these questions were not asked the question analyzed here.
} 
series clearly move together. The Spearman rank correlation, which measures the ordinal covariation of the two time series, is 0.80 . We think it premature with only one year of data to attempt to assess whether expectations of mutual fund growth lead, coincide with, or lag the S\&P realizations. However, it may become possible to assess this relationship when a longer time series becomes available.

\subsection{Probabilistic Job Expectations}

Respondents to the Survey of Consumers who are currently working were posed two probabilistic questions about job prospects. The composition of employment changes over time for various reasons: regular seasonal variation in employment, business-cycle fluctuations, and longterm changes associated with changes in the demographic composition of the population. For these reasons, care needs to be taken in interpretation of the time-series variation in responses to the job questions. Volatility in the responses could reflect changes in the composition of the respondents. To remove a particularly important source of cyclical fluctuation in composition, we assign to the currently unemployed a 100 percent chance of job loss, as we did in the Dominitz and Manski (1997b) analysis of SEE data.

The possible compositional changes notwithstanding, the findings on expectations of job loss (V255) and re-employment prospects (V256) are interesting. The results reported in Tables $1 \mathrm{G}$ and 1H are very similar to those found for SEE respondents in the period 1994-1998 (Manski and Straub, 2000). The important new finding is that expectations vary little month-to-month. The mean percent chance of job loss ranges from 19.0 in Sep-02 to 24.7 in Feb-03, and the median ranges from 5 to 10 percent. The mean likelihood of finding and accepting a job "at least as good" as the current 
one ranges from 45.2 percent in Apr-03 to 49.6 in Aug-02, and the median remains constant at 50 percent. These results provide further evidence that personal expectations are not very volatile. Note also that nonresponse is minimal: $1 \%$ overall for job loss, and 3\% overall for the reemployment question.

\subsection{Covariation Among Expectations}

To conclude our analysis of temporal fluctuations in expectations, we examine how the eight time-series shown in Tables $1 \mathrm{~A}-1 \mathrm{H}$ covary over the 12-month period. Table 2 uses the Spearman rank correlation to describe the ordinal covariation between each pair of time series. We use the ranks of the relative scores to summarize the time series of responses to each qualitative question; thus, variable BUS12 is ordered from a minimum rank of 1 in Mar-03 to a maximum rank of 12 in May-03. We use the mean percent-chance to summarize the time series of responses to each probabilistic question; thus, variable V250 is ordered from a minimum rank of 1 in Oct-02 to a maximum rank of 12 in Jun-02.

The table shows that the responses to each qualitative question covary very strongly with each other. The rank correlations of all pairs of the variables (BUS12, PEXP, BEXP, INEXQ1) lie in the range $[0.72,0.93]$. This suggests that, from an ordinal perspective, the four qualitative variables provide largely overlapping information on consumers' expectations.

In contrast, the responses to the four probabilistic questions covary weakly, if at all, with one another. The rank correlations of all pairs of the variables (V250, V252, V255, V256) lie in the range $[-0.12,0.23]$. Thus, each of these four variables appears to provide distinct information on 
consumers' expectations.

Finally, consider the covariation of responses to the qualitative and probabilistic questions. Responses to the qualitative macroeconomic questions (BUS12 and BEXP) covary moderately with responses to the mutual-fund investment question (V250); the rank correlations are 0.58 and 0.46 respectively. However, responses to BUS12 and BEXP covary only weakly with responses to the probabilistic question about personal income growth (V252); these rank correlations are 0.23 and 0.16. The responses to V252 covary more strongly with those to the two qualitative personalfinance questions. The pair (V252, PEXP) has rank correlation 0.49, while (V252, INEXQ1) has rank correlation 0.65 . Viewed in their entirety, these findings make good sense; the highest rank correlations occur between variables that inquire about the most closely related events.

\section{Cross-Sectional Variation in Expectations}

Table 1 shows clearly that, at any point in time, expectations vary across the population. In each month, a substantial fraction of respondents answering the qualitative questions report that conditions, be they microeconomic or macroeconomic, will improve, whereas a substantial fraction report that conditions will worsen. Similarly, probabilistic expectations vary substantially across respondents. This is evident from the large standard deviations and interquartile ranges shown in Tables 1E through 1G.

This section examines how expectations vary with respondent attributes. The analysis pools the samples of initial interviews from Jun-02 through May-03, which are independent random 
samples of the population, yielding a total sample size of 3543. Cross-sectional variation may reflect differences in the way that persons interpret the questions posed, rather than differences in their expectations per se. This possibility seems most acute for the qualitative questions, as respondents may reasonably differ in how they interpret the term "business conditions" or "better off financially." The discussion below focuses primarily on the percent-chance questions, which should be less susceptible to variation in interpretation.

\subsection{Univariate Analysis}

Table 3 reports a univariate analysis examining the cross-sectional variation in expectations with each of several personal attributes.

\section{Percent Chance Investment Expectations}

The results on investment expectations are particularly intriguing. In principle, all members of the population have access to the same publicly available information about the stock market. Hence, variation in responses to question V250 must reflect variation in the processing of public information and/or variation in private information. We conjecture that most people have no meaningful private information about the market. If so, then the observed variation in expectations mainly reflects differences in the way people process the available public information. The empirical existence of strong heterogeneity in investment expectations, already evident in Table 1E,

runs counter to the conventional rational expectations assumption that all persons process information in the same way. 
Table 3A shows that some of this heterogeneity is systematic, in the sense that persons with different demographic attributes have different distributions of expectations. We find that males tend to be more optimistic than females. Optimism increases with schooling, from a mean (median) of 38.4 (40) for those with no postsecondary education to 45.3 (50) for those with a bachelor's degree. Younger persons are more optimistic than older ones, with the mean (median) falling from a 46.3 (50) percent chance for respondents under age 35 to a 33.5 (25) percent chance for those 65 and older. Most of this decline occurs at the highest age group. We also find variation by marital status, which we conjecture to reflect variation by age. Most optimistic are the never married, who tend to be young, and least optimistic are the widowed, who tend to be old. Finally, we find that nonresponse is highest in the parts of the population that tend to be least optimistic.

These findings raise important behavioral questions: (1) Why do investment expectations vary so sharply and so systematically across the population? (2) How does the observed variation in expectations affect investment behavior? The data available in the Survey of Consumers do not enable us to answer these questions here, but we think them important subjects for future research.

\section{Percent Chance Income Expectations}

Much of the variation in income expectations, described in Table 3B, resembles that found in investment expectations. Males tend to be more optimistic than females, the young are more optimistic than the old, and optimism increases with schooling. Unlike the case of a mutual fund investment, income realizations actually do vary cross-sectionally. Moreover, income growth does tend to be higher for males, the young, and the better educated. Thus, the findings on income expectations broadly conform to observed variation in realizations, as has been found repeatedly 
with expectations of personal events reported in SEE over the past decade. See, for example, Dominitz and Manski (1997b) on health insurance coverage and job loss probabilities and Dominitz (2001) on the central tendency and spread of income expectations.

\section{Qualitative Expectations}

Table $3 \mathrm{C}$ describes the cross-sectional variation in responses to question BEXP, the more precisely worded of the two qualitative questions on national business conditions. The responses show the same ordinal patterns as the responses to investment question V250. Males are more optimistic than females. Whites are more optimistic than others. Younger persons are more optimistic than older ones. Optimism increases with schooling. Similarly, the variation in family income expectations (INEXQ1), described in Table 3D, resembles that found for probabilistic expectations of personal income growth.

\subsection{Best Linear Predictors}

To jointly describe how expectations vary with multiple personal attributes and over time, Table 4 presents best linear predictors under square loss of the probabilistic responses to the investment and income questions. All but one of the ordinal patterns found in the univariate analysis of Table 3 remain intact in this multivariate analysis. The one ordinal pattern that notably wanes is the substantial variation in expectations with marital status, which corroborates our conjecture that the univariate marital-status pattern actually reflects a pattern of variation with age. 


\section{$\underline{\text { 5. Temporal Fluctuations in Individual Expectations }}$}

The analysis of Section 3 examined how the distribution of expectations changes over time. With panel data available, another perspective on temporal fluctuations can be obtained from analysis of changes over time in individual expectations. Although the Michigan survey does not sample the same individuals each month, it does sample some individuals twice, at six-month intervals. These data enable study of fluctuations in individual expectations.

Table 5 shows linear auto-regressions of individual probabilistic expectations on the same expectations lagged six months. We have also performed nonparametric auto-regressions, not presented here, which yield findings very similar to those obtained with the linear fits. All autoregressions have substantial predictive power, lagged expectations being a strongly positive predictor of expectations six months later. Thus, we find considerable stability over time in individual expectations.

This notwithstanding, we find that individual expectations do vary to some extent in the six months between interviews. The slopes of the autoregressions of expectations for personal events are steeper than those for investment outcomes. This suggests greater volatility in the latter expectations.

Table 6 shows transition matrices for responses to the ICS questions BUSI2 and PEXP. Each matrix presents the probability that a person gives each of the three possible responses in the re-interview conducted between Dec-02 and May-03, conditional on his response six months earlier. The matrices show substantial positive dependency, with the probability of repeating the same 
response usually exceeding one-third by a substantial margin. The one exception is the rarely chosen BUS12 response "pro-con."

Observe that the transition probabilities between positive and negative assessments of the future are much higher for responses to the macroeconomic question BUS12 than to the microeconomic question PEXP. In particular, 36\% of those who initially foresee "good" business conditions subsequently report "bad", and $21 \%$ of those who initially foresee "bad" conditions subsequently report "good." In contrast, just 5\% of those who initially think their family finances will improve subsequently expect them to worsen, and just $16 \%$ with an initial report of "worse" later say "better." These results add yet further evidence that the qualitative expectations of macroeconomic events elicited in the Survey of Consumers are more volatile than the expectations of personal events.

\section{$\underline{\text { 6. Concluding Questions }}$}

The Index of Consumer Sentiment is now constructed from responses to five questions, three of which concern economic expectations, with each question given equal weight. The original "index of consumer attitudes" included responses to a price expectations question as well. Except for eliminating the question on price expectations, the definition of the index appears to have been very stable for fifty years. Yet one of the principal investigators long ago called for careful reconsideration of the index in the concluding paragraph of her paper:

"The index of consumer attitudes which was related here to individual purchases is still in an 
experimental stage. Ahead is the challenging problem of seeing whether closer correlations with purchases can be established by improving the index — by adding new series, revising the weighting of components, and refining the attitudinal measures themselves" (Mueller, 1957, p. 965).

Almost a half-century later, we take up the challenge to improve the measurement of consumer confidence.

The findings reported in this paper suggest that improvement is feasible. Drawing on these findings, we close with three major questions regarding the effective measurement of consumer confidence:

1. Should the Survey of Consumers and similar surveys ask consumers about national business conditions?

2. Should the qualitative questions of the Survey of Consumers be continued as is, complemented by probabilistic questions, or replaced by probabilistic questions?

3. Should the responses to the various questions be aggregated into an index or presented separately? If an index is thought desirable, how should it be constructed?

Although it is premature to assert definitive answers to these questions, we feel ready to offer tentative responses, drawing in part on the findings of this paper. Regarding the first question, we do not see an obvious rationale for asking consumers about such distant, ambiguous phenomena as 
"national business conditions." The respondents are not experts, as in the Livingston panel and the Survey of Professional Forecasters. ${ }^{4}$ If the objective is to use expectations data to predict personal consumption, expectations for the nation should be relevant only to the extent that they are an input into formation of personal expectations. Hence, why not ask more questions that probe personal expectations directly, and eliminate the questions on national business conditions? The case for this change is especially strong if the month-to-month changes in the ICS are being driven largely by spurious volatility in the responses to question BUS12.

We do think that consumers may usefully be queried about well-defined macroeconomic events that are directly relevant to their personal lives. The question eliciting expectations for growth in the value of a mutual-fund investment exemplifies what we have in mind. One might similarly elicit expectations for aspects of government policy that directly affect consumer finances; for example, tax policy and social security policy.

Regarding the second question, we think that the traditional qualitative questions of consumer-confidence surveys should at least complemented by, and perhaps replaced by, probabilistic questions inquiring about well-defined events. Although probabilistic questioning has obvious conceptual advantages, economists had little experience with it before the early 1990s, and skepticism about its feasibility was rampant. However, substantial experience has accumulated in the past ten years through the administration of probabilistic questions in SEE and in such major national surveys as the Health and Retirement Study (Hurd and McGarry, 1995, 2002) and the

\footnotetext{
${ }^{4}$ These surveys of experts are described in Caskey (1985) and Keane and Runkle (1990), respectively.

${ }^{5}$ A possible scientific reason to retain questions on national business conditions is to study expectations formation; one may want to understand how individuals use their perspectives on national conditions to form their personal expectations. This objective is distinct from the longstanding purpose of the Michigan survey. Moreover, expectations formation may be much better studied through intensive interviewing than through short telephone surveys.
} 
National Longitudinal Study of Youth-1997 Cohort (Fischhoff et al., 2000; Dominitz, Manski, and Fischhoff, 2001). This experience, plus the new findings on the Survey of Consumers reported in this paper, make plain that probabilistic questioning is feasible and yields richer information on consumer beliefs than is obtainable with traditional qualitative questions.

Finally, we suggest that the producers of consumer confidence statistics prominently report their findings for separate questions. The responses to separate questions are much more readily interpretable than are monthly reports of an index constructed from disparate, non-commensurate elements. We do not go so far as to suggest a halt to reports of indices; simple summaries of masses of data often are a practical necessity. However, we do think it long overdue to reconsider the particular structure of the ICS and similar indices. 


\section{$\underline{\text { References }}$}

Batchelor, R. and P. Dua (1998), "Improving Macro-economic Forecasts: The Role of Consumer Confidence," International Journal of Forecasting, 14, 71-81.

Carroll, C., J. Fuhrer, and D. Wilcox (1994), "Does Consumer Sentiment Forecast Household Spending: If so, Why?” American Economic Review, 84, 1397-1408.

Caskey, J. (1985). "Modeling the Formation of Price Expectations: A Bayesian Approach," American Economic Review, 75, 768-776.

Curtin, R. (1982), "Indicators of Consumer Behavior: The University of Michigan Surveys of Consumers," Public Opinion Quarterly, 46, 340-352.

Das, M., J. Dominitz, and A. van Soest (1999), “Comparing Predictions and Outcomes: Theory and Application to Income Changes," Journal of the American Statistical Association, 94, 75-85.

Dominitz, J. (2001), "Estimation of Income Expectations Model Using Expectations and Realizations Data," Journal of Econometrics, 102, 165-195.

Dominitz, J. and C. Manski (1997a), "Using Expectations Data to Study Subjective Income Expectations," Journal of the American Statistical Association, 92, 855-867.

Dominitz, J. and C. Manski (1997b), "Perceptions of Economic Insecurity: Evidence from the Survey of Economic Expectations,” Public Opinion Quarterly, 61, 261-287.

Dominitz, J. and C. Manski (1999), "The Several Cultures of Research on Subjective Expectations," In: Smith, J. and R. Willis (eds.) Wealth, Work, and Health: Essays in Honor of F. Thomas Juster, University of Michigan Press, Ann Arbor.

Dominitz, J, C. Manski, and B. Fischhoff(2001), "Who are Youth At-Risk?: Expectations Evidence in the NLSY-97," in R. Michael (editor), Social Awakenings: Adolescents'Behavior as Adulthood Approaches, New York: Russell Sage Foundation, 230-257.

Federal Reserve Consultant Committee on Consumer Survey Statistics (1955), Smithies Committee report in Reports of the Federal Reserve Consultant Committees on Economic Statistics, Hearings of the Subcommittee on Economic Statistics of the Joint Committee on the Economic Report, 84th US Congress.

Fischhoff, B., A. Parker, W. de Bruin, J. Downs, C. Palmgren, R. Dawes, and C. Manski (2000), “Teen Expectations for Significant Life Events," Public Opinion Quarterly, 64, 189-205.

Fuhrer, Jeffrey C. (1988), "On the Information Content of Consumer Survey Expectations," Review of Economics and Statistics, 140-144. 
Hurd, M. and K. McGarry (1995), "Evaluation of the Subjective Probabilities of Survival in the Health and Retirement Study," Journal of Human Resources, 30, S268-S292.

Hurd, M. and K. McGarry (2002), "The Predictive Validity of Subjective Probabilities of Survival," The Economic Journal, 112, 966-985.

Juster, T. (1964), Anticipations and Purchases: An Analysis of Consumer Behavior, Princeton: Princeton University Press.

Katona, G. (1957), "Federal Reserve Board Committee Reports on Consumer Expectations and Savings Statistics," Review of Economics and Statistics, 39, 40-46.

Keane, M., and D. Runkle (1990), "Testing the Rationality of Price Forecasters: New Evidence from Panel Data," American Economic Review, 80, 714-734.

Kumar, V., R. Leone, and J. Gaskins (1995), “Aggregate and Disaggregate Sector Forecasting Using Consumer Confidence Measures," International Journal of Forecasting, 11, 361-377.

Linden, F. (1982), “The Consumer as Forecaster,” Public Opinion Quarterly, 46, 353-360.

Madsen, J. and M. McAleer (2000), "Direct Tests of the Permanent Income Hypothesis under Uncertainty, Inflationary Expectations and Liquidity Constraints," Journal of Macroeconomics, 22, 229-252.

Manski, C. (1990), "The Use of Intentions Data to Predict Behavior: A Best Case Analysis," Journal of the American Statistical Association, 85, 934-940.

Manski, C., and J. Straub (2000), "Worker Perceptions of Job Insecurity in the Mid-1990s: Evidence from the Survey of Economic Expectations," Journal of Human Resources, 35, 447-479.

Matsusaka, J. and A. Sbordone (1995), "Consumer Confidence and Economic Fluctuations," Economic Inquiry, 33, 296-318.

Mueller, E. (1957), "Effects of Consumer Attitudes on Purchases," American Economic Review, 47, 946-965.

National Bureau of Economic Research (1960), The Quality and Economic Significance of Anticipations Data, Special Conference Series, Princeton: Princeton University Press.

Tobin, J. (1959). “On the Predictive Value of Consumer Intentions and Attitudes," Review of Economics and Statistics, 41, 1-11. 


\section{Appendix A}

The Index of Consumer Sentiment

The Index of Consumer Sentiment (ICS) is calculated using the

following formula, in which the component questions $\left(\mathrm{x}_{1} \ldots \mathrm{x}_{5}\right)$ are listed below. The relative scores of the 5 component questions are used in the equation and are defined as the percent giving favorable replies minus the percent giving unfavorable replies, plus 100. Each relative score is rounded to the nearest whole number. The denominator of the formula is the 1966 base period total of 6.7558, and the added constant ( $\mathrm{n}$ ) is to correct for sample design changes from the 1950s. Prior to December 1981, n=2.7; for December 1981 and after, $n=2.0$.

\section{ICS $=\frac{X_{1}+X_{2}+X_{3}+X_{4}+X_{5}}{6.7558}+n$}

The Index of Consumer Sentiment is derived from the following five questions:

$\mathrm{x}_{1}=$ "We are interested in how people are getting along financially these days. Would you say that you (and your family living there) are better off or worse off financially than you were a year ago?"

$\mathrm{x}_{2}=$ "Now looking ahead--do you think that a year from now you (and your family living there) will be better off financially, or worse off, or just about the same as now?"

$\mathrm{x}_{3}=$ "Now turning to business conditions in the country as a whole-do you think that during the next twelve months we'll have good times financially, or bad times, or what?"

$\mathrm{x}_{4}=$ "Looking ahead, which would you say is more likely--that in the country as a whole we'll have continuous good times during the next five years or so, or that we will have periods of widespread unemployment or depression, or what?"

$\mathrm{x}_{5}=$ "About the big things people buy for their homes-such as fumiture, a refrigerator, stove, television, and things like that. Generally speaking, do you think now is a good or bad time for people to buy major household items?" 


\section{Appendix B: Qualitative Expectations Questions on the Survey of Consumers}

BUS12 (ICS question)

Now turning to business conditions in the country as a whole--do you think that during the next 12 months we'll have good times financially, or bad times, or what?

1. Good times

2. Good with qualifications

3. Pro-con

4. Bad with qualifications

5. Bad times

PEXP (ICS question)

Now looking ahead--do you think that a year from now you (and your family living there) will be better off financially, or worse off, or just about the same as now?

1. Will be better off

3. Same

5. Will be worse off

BEXP

And how about a year from now, do you expect that in the country as a whole business conditions will be better, or worse than they are at present, or just about the same?

1. Better a year from now

3. About the same

5. Worse a year from now

\section{INEXQ1}

During the next 12 months, do you expect your (family) income to be higher or lower than during the past year?

1. Higher

3. Same

5. Lower 


\section{Appendix C: "Percent Chance" Expectations Questions on the Survey of Consumers}

V250

The next question is about investing in the stock market. Please think about the type of mutual fund known as a diversified stock fund. This type of mutual fund holds stock in many different companies engaged in a wide variety of business activities. Suppose that tomorrow someone were to invest one thousand dollars in such a mutual fund. Please think about how much money this investment would be worth one year from now.

What do you think is the percent chance that this one thousand dollar investment will increase in value in the year ahead, so that it is worth more than one thousand dollars one year from now?

V251

What do you think is the percent chance that this one thousand dollar investment will increase in value by more than ten percent in the year ahead, so that is it worth more than eleven hundred dollars one year from now?

V252

Next I would like to ask you about your OWN (personal) income prospects in the next twelve months. What do you think is the percent chance that your income in the next twelve months will be higher than your income in the past twelve months?

V253

What do you think is the percent chance that your OWN (personal) income in the next twelve months will be more than ten percent higher than your income in the past twelve months?

V255

What do you think is the percent chance that you will lose your job during the next twelve months?

V256

If you were to lose your job during the next twelve months, what do you think is the percent chance that the job you eventually find and accept would be at least as good as your current job in terms of wages and benefits? 
Table 1A: ICS Qualitative Expectations for Business Conditions, by Month (BUS12)

\begin{tabular}{|c|c|ccccc|c|}
\hline & & \multicolumn{5}{|c|}{ Response Frequencies (percent of sample) } & Relative \\
\cline { 3 - 7 } month & $\mathrm{N}$ & good & pro-con & $\underline{\text { bad }}$ & Don't Know & No Response & Score \\
\cline { 1 - 6 } Jun-02 & 501 & 47.9 & 7.2 & 34.7 & 7.4 & 2.8 & 113.2 \\
Jul-02 & 501 & 37.5 & 6.0 & 48.5 & 6.0 & 2.0 & 89.0 \\
Aug-02 & 500 & 40.0 & 7.8 & 43.6 & 7.6 & 1.0 & 96.4 \\
Sep-02 & 501 & 41.1 & 4.4 & 42.3 & 7.4 & 4.8 & 98.8 \\
Oct-02 & 502 & 31.5 & 4.2 & 55.6 & 5.4 & 3.4 & 75.9 \\
Nov-02 & 504 & 40.1 & 5.2 & 45.0 & 5.0 & 4.8 & 95.0 \\
Dec-02 & 500 & 39.6 & 5.0 & 47.2 & 4.4 & 3.8 & 92.4 \\
Jan-03 & 501 & 33.1 & 6.2 & 54.7 & 3.8 & 2.2 & 78.4 \\
Feb-03 & 501 & 26.6 & 4.8 & 60.9 & 4.2 & 3.6 & 65.7 \\
Mar-03 & 504 & 27.6 & 4.2 & 62.1 & 4.4 & 1.8 & 65.5 \\
Apr-03 & 500 & 38.0 & 5.2 & 49.8 & 4.6 & 2.4 & 88.2 \\
May-03 & 500 & 54.4 & 2.2 & 36.0 & 4.6 & 2.8 & 118.4 \\
\hline
\end{tabular}

Table 1B: ICS Qualitative Expectations for Family Finances, by Month (PEXP)

\begin{tabular}{|c|c|c|c|c|c|c|c|}
\hline \multirow[b]{2}{*}{$\underline{\text { month }}$} & \multirow[b]{2}{*}{$\underline{\mathrm{N}}$} & \multicolumn{5}{|c|}{ Response Frequencies (percent of sample) } & \multirow{2}{*}{$\begin{array}{c}\text { Relative } \\
\text { Score }\end{array}$} \\
\hline & & better off & $\underline{\text { same }}$ & $\underline{\text { worse off }}$ & Don't Know & No Response & \\
\hline Jun-02 & 501 & 42.7 & 48.1 & 5.6 & 3.4 & 0.2 & 137.1 \\
\hline Jul-02 & 501 & 40.1 & 48.5 & 8.8 & 2.6 & 0.0 & 131.3 \\
\hline Aug-02 & 500 & 39.0 & 50.2 & 8.0 & 2.8 & 0.0 & 131.0 \\
\hline Sep-02 & 501 & 41.1 & 45.3 & 11.0 & 2.6 & 0.0 & 130.1 \\
\hline Oct-02 & 502 & 41.2 & 43.4 & 11.8 & 3.6 & 0.0 & 129.5 \\
\hline Nov-02 & 504 & 40.1 & 47.2 & 10.1 & 2.6 & 0.0 & 130.0 \\
\hline Dec-02 & 500 & 42.8 & 48.8 & 6.4 & 2.0 & 0.0 & 136.4 \\
\hline Jan-03 & 501 & 37.9 & 47.7 & 12.6 & 1.8 & 0.0 & 125.4 \\
\hline Feb-03 & 501 & 38.7 & 46.5 & 12.4 & 2.2 & 0.2 & 126.3 \\
\hline Mar-03 & 504 & 40.5 & 43.1 & 13.1 & 3.2 & 0.2 & 127.4 \\
\hline Apr-03 & 500 & 39.0 & 48.2 & 9.8 & 2.6 & 0.4 & 129.2 \\
\hline May-03 & 500 & 43.8 & 46.8 & 7.6 & 1.8 & 0.0 & 136.2 \\
\hline
\end{tabular}

\footnotetext{
${ }^{1}$ As calculated in the Index of Consumer Sentiment, the relative score equals the percent favorable minus the percent unfavorable plus 100 .
} 
Table 1C: Qualitative Expectations for Business Conditions, by Month (BEXP)

\begin{tabular}{|c|c|c|c|c|c|c|c|}
\hline \multirow[b]{2}{*}{ month } & \multirow[b]{2}{*}{$\underline{\mathrm{N}}$} & \multicolumn{5}{|c|}{ Response Frequencies (percent of sample) } & \multirow{2}{*}{$\begin{array}{c}\text { Relative } \\
\text { Score }\end{array}$} \\
\hline & & better & same & worse & Don't Know & No Response & \\
\hline Jun-02 & 501 & 41.1 & 43.7 & 12.4 & 2.6 & 0.2 & 128.7 \\
\hline Jul-02 & 501 & 33.9 & 46.3 & 18.4 & 1.4 & 0.0 & 115.6 \\
\hline Aug-02 & 500 & 42.6 & 43.4 & 13.0 & 1.0 & 0.0 & 129.6 \\
\hline Sep-02 & 501 & 39.5 & 40.9 & 16.0 & 3.4 & 0.2 & 123.6 \\
\hline Oct-02 & 502 & 31.1 & 45.0 & 19.9 & 3.8 & 0.2 & 111.2 \\
\hline Nov-02 & 504 & 37.9 & 40.9 & 18.7 & 2.2 & 0.4 & 119.3 \\
\hline Dec-02 & 500 & 35.6 & 45.6 & 16.4 & 2.4 & 0.0 & 119.2 \\
\hline Jan-03 & 501 & 28.3 & 44.5 & 25.6 & 1.4 & 0.2 & 102.8 \\
\hline Feb-03 & 501 & 30.5 & 41.1 & 24.2 & 3.6 & 0.6 & 106.4 \\
\hline Mar-03 & 504 & 29.6 & 40.5 & 26.2 & 3.8 & 0.0 & 103.4 \\
\hline Apr-03 & 500 & 38.8 & 39.4 & 20.0 & 1.4 & 0.4 & 118.8 \\
\hline May-03 & 500 & 45.2 & 40.4 & 13.0 & 1.4 & 0.0 & 132.2 \\
\hline
\end{tabular}

Table 1D: Qualitative Expectations for Family Income, by Month (INEXQ1)

\begin{tabular}{|c|c|ccccc|c|}
\hline & & \multicolumn{5}{|c|}{ Response Frequencies (percent of sample) } & \multirow{2}{*}{$\begin{array}{c}\text { Relative } \\
\text { month }\end{array}$} \\
\cline { 3 - 7 } & $\underline{\mathrm{N}}$ & $\underline{\text { higher }}$ & $\underline{\text { same }}$ & $\underline{\text { lower }}$ & Don't Know No Response & Score \\
\cline { 3 - 7 } Jun-02 & 501 & 62.5 & 23.2 & 13.2 & 1.2 & 0.0 & 149.3 \\
Jul-02 & 501 & 63.1 & 21.0 & 15.6 & 0.4 & 0.0 & 147.5 \\
Aug-02 & 500 & 62.4 & 21.6 & 14.8 & 1.2 & 0.0 & 147.6 \\
Sep-02 & 501 & 63.5 & 23.6 & 12.0 & 1.0 & 0.0 & 151.5 \\
Oct-02 & 502 & 59.4 & 23.9 & 15.9 & 0.6 & 0.2 & 143.4 \\
Nov-02 & 504 & 61.3 & 23.6 & 13.5 & 1.6 & 0.0 & 147.8 \\
Dec-02 & 500 & 62.4 & 21.6 & 14.6 & 1.0 & 0.4 & 147.8 \\
Jan-03 & 501 & 59.7 & 23.2 & 17.0 & 0.2 & 0.0 & 142.7 \\
Feb-03 & 501 & 59.1 & 25.2 & 14.8 & 0.8 & 0.2 & 144.3 \\
Mar-03 & 504 & 60.5 & 22.2 & 16.7 & 0.4 & 0.2 & 143.9 \\
Apr-03 & 500 & 58.8 & 25.2 & 14.6 & 1.2 & 0.2 & 144.2 \\
May-03 & 500 & 58.8 & 26.4 & 13.8 & 0.6 & 0.4 & 145.0 \\
\hline
\end{tabular}

${ }^{1}$ As calculated in the Index of Consumer Sentiment, the relative score equals the percent favorable minus the percent unfavorable plus 100. 
Table 1E: Percent Chance of Mutual Fund Investment Increase, by Month (V250)

\begin{tabular}{|c|c|cc|ccc|cc|}
\hline & & & & \multicolumn{3}{|c|}{ Quantiles } & \multicolumn{2}{c|}{ (nonrespondents) } \\
\cline { 5 - 8 } month & $\underline{N}$ & & & & & & $\underline{\text { Don't }}$ & $\underline{\text { No }}$ \\
(respondents) & $\underline{\text { mean }}$ & $\underline{\text { std dev }}$ & $\underline{0.25}$ & $\underline{0.50}$ & $\underline{0.75}$ & $\underline{\text { Know }}$ & $\underline{\text { Response }}$ \\
Jul-02 & 448 & 45.3 & 27.8 & 20 & 50 & 70 & 40 & 13 \\
Aug-02 & 459 & 41.0 & 27.8 & 20 & 50 & 60 & 31 & 11 \\
Sep-02 & 460 & 41.0 & 27.8 & 20 & 40 & 60 & 26 & 14 \\
Oct-02 & 469 & 39.6 & 28.8 & 10 & 40 & 60 & 23 & 9 \\
Nov-02 & 458 & 39.3 & 25.9 & 20 & 40 & 50 & 33 & 11 \\
Dec-02 & 465 & 44.5 & 29.6 & 20 & 50 & 70 & 27 & 12 \\
Jan-03 & 464 & 43.3 & 29.0 & 20 & 50 & 60 & 32 & 4 \\
Feb-03 & 467 & 42.3 & 28.8 & 20 & 50 & 60 & 25 & 9 \\
Mar-03 & 468 & 40.8 & 28.1 & 20 & 40 & 60 & 26 & 7 \\
Apr-03 & 482 & 39.8 & 28.5 & 15 & 40 & 60 & 17 & 5 \\
May-03 & 460 & 41.5 & 29.5 & 19 & 40 & 65 & 30 & 10 \\
\hline
\end{tabular}

Table 1F: Percent Chance of Personal Income Increase, by Month (V252)

\begin{tabular}{|c|c|c|c|c|c|c|c|c|c|}
\hline \multirow[b]{2}{*}{$\underline{\text { month }}$} & \multirow[b]{2}{*}{$\frac{\mathrm{N}}{\text { (respondents) }}$} & \multirow[b]{2}{*}{$\underline{\text { mean }}$} & \multirow[b]{2}{*}{$\underline{\text { std dev }}$} & \multicolumn{3}{|c|}{ Quantiles } & \multicolumn{3}{|c|}{$\mathrm{N}$ (nonrespondents) } \\
\hline & & & & $\underline{0.25}$ & $\underline{0.50}$ & $\underline{0.75}$ & $\underline{\text { Don't }}$ & $\begin{array}{c}\frac{\text { No }}{\text { Response }} \\
\underline{\underline{n}}\end{array}$ & $\frac{\text { Not }}{\text { Applicable }}$ \\
\hline Jun-02 & 480 & 53.3 & 36.4 & 10 & 50 & 80 & 15 & 6 & 0 \\
\hline Jul-02 & 479 & 51.1 & 37.3 & 10 & 50 & 85 & 14 & 7 & 1 \\
\hline Aug-02 & 475 & 50.9 & 36.9 & 10 & 50 & 80 & 14 & 10 & 1 \\
\hline Sep-02 & 486 & 53.0 & 37.8 & 10 & 50 & 90 & 11 & 3 & 1 \\
\hline Oct-02 & 472 & 49.8 & 36.2 & 10 & 50 & 80 & 18 & 10 & 2 \\
\hline Nov-02 & 483 & 52.4 & 37.7 & 10 & 50 & 90 & 10 & 8 & 3 \\
\hline Dec-02 & 483 & 54.2 & 36.1 & 20 & 50 & 85 & 13 & 3 & 1 \\
\hline Jan-03 & 487 & 49.7 & 37.5 & 10 & 50 & 80 & 8 & 4 & 2 \\
\hline Feb-03 & 483 & 48.1 & 36.5 & 10 & 50 & 80 & 11 & 5 & 2 \\
\hline Mar-03 & 496 & 52.4 & 35.7 & 15 & 50 & 80 & 7 & 0 & 1 \\
\hline Apr-03 & 478 & 48.6 & 37.0 & 10 & 50 & 80 & 10 & 10 & 2 \\
\hline May-03 & 483 & 47.9 & 37.4 & 10 & 50 & 80 & 6 & 6 & 5 \\
\hline
\end{tabular}


Table 1G: Percent Chance of Job Loss, by Month

(V255)

\begin{tabular}{|c|c|c|c|c|c|c|c|c|c|}
\hline \multirow[b]{2}{*}{ month } & \multirow[b]{2}{*}{$\stackrel{\mathrm{N}}{\text { (respondents) }}$} & \multirow[b]{2}{*}{ mean } & \multirow[b]{2}{*}{$\underline{\text { std dev }}$} & \multicolumn{3}{|c|}{ Quantiles } & \multicolumn{3}{|c|}{$\mathrm{N}$ (nonrespondents) } \\
\hline & & & & $\underline{0.25}$ & $\underline{0.50}$ & $\underline{0.75}$ & $\begin{array}{l}\text { Don't } \\
\text { Know }\end{array}$ & $\begin{array}{c}\text { No } \\
\underline{\text { Response }}\end{array}$ & $\begin{array}{c}\text { Not } \\
\text { Applicable }\end{array}$ \\
\hline$\overline{\text { Jun-02 }}$ & 359 & $\overline{20.6}$ & 30.6 & 0 & $\overline{10}$ & 25 & 2 & 1 & 139 \\
\hline Jul-02 & 337 & 19.9 & 30.2 & 0 & 5 & 20 & 3 & 0 & 161 \\
\hline Aug-02 & 350 & 19.1 & 29.4 & 0 & 5 & 20 & 2 & 0 & 148 \\
\hline Sep-02 & 339 & 19.0 & 29.5 & 0 & 5 & 20 & 2 & 1 & 159 \\
\hline Oct-02 & 330 & 20.4 & 31.7 & 0 & 5 & 20 & 7 & 3 & 162 \\
\hline Nov- 02 & 326 & 22.8 & 33.6 & 0 & 5 & 30 & 8 & 5 & 165 \\
\hline Dec-02 & 348 & 21.7 & 32.2 & 0 & 10 & 25 & 2 & 1 & 149 \\
\hline Jan-03 & 356 & 20.1 & 30.3 & 0 & 5 & 25 & 0 & 1 & 144 \\
\hline Feb-03 & 355 & 24.7 & 34.5 & 0 & 10 & 35 & 1 & 0 & 145 \\
\hline Mar-03 & 375 & 22.9 & 32.7 & 0 & 10 & 30 & 1 & 2 & 126 \\
\hline Apr-03 & 332 & 21.1 & 31.4 & 0 & 5 & 25 & 0 & 2 & 166 \\
\hline May-03 & 344 & 21.1 & 32.4 & 0 & 5 & 20 & 3 & 2 & 151 \\
\hline
\end{tabular}

Table 1H: Percent Chance of Re-employment, by Month (V256)

\begin{tabular}{|c|c|c|c|c|c|c|c|c|c|}
\hline \multirow[b]{2}{*}{ month } & \multirow[b]{2}{*}{$\stackrel{\underline{\mathrm{N}}}{\text { (respondents) }}$} & \multirow[b]{2}{*}{ mean } & \multirow[b]{2}{*}{$\underline{\text { std dev }}$} & \multicolumn{3}{|c|}{ Quantiles } & \multicolumn{3}{|c|}{$\mathrm{N}$ (nonrespondents) } \\
\hline & & & & $\underline{0.25}$ & $\underline{0.50}$ & $\underline{0.75}$ & $\begin{array}{l}\text { Don't } \\
\text { Know }\end{array}$ & $\begin{array}{c}\text { No } \\
\text { Response }\end{array}$ & $\frac{\text { Not }}{\text { Applicable }}$ \\
\hline Jun-02 & 323 & 47.5 & 32.3 & 20 & 50 & 75 & 6 & 4 & 168 \\
\hline Jul-02 & 312 & 49.1 & 32.4 & 20 & 50 & 80 & 5 & 3 & 181 \\
\hline Aug-02 & 327 & 49.6 & 32.7 & 20 & 50 & 80 & 3 & 2 & 168 \\
\hline Sep-02 & 318 & 44.6 & 32.7 & 10 & 50 & 75 & 4 & 2 & 177 \\
\hline Oct-02 & 305 & 47.0 & 33.2 & 15 & 50 & 75 & 7 & 5 & 185 \\
\hline Nov-02 & 300 & 47.1 & 33.7 & 15 & 50 & 80 & 7 & 3 & 194 \\
\hline Dec-02 & 313 & 47.6 & 32.5 & 20 & 50 & 75 & 6 & 2 & 179 \\
\hline Jan-03 & 322 & 44.4 & 32.0 & 10 & 50 & 75 & 6 & 3 & 170 \\
\hline Feb-03 & 310 & 47.5 & 31.6 & 20 & 50 & 75 & 6 & 3 & 182 \\
\hline Mar-03 & 336 & 46.2 & 33.9 & 20 & 50 & 80 & 3 & 3 & 162 \\
\hline Apr-03 & 303 & 45.2 & 33.1 & 15 & 50 & 75 & 2 & 4 & 191 \\
\hline May-03 & 318 & 47.1 & 33.1 & 10 & 50 & 75 & 5 & 0 & 177 \\
\hline
\end{tabular}


Table 2: Spearman Rank Correlations Among Aggregated Expectations

\begin{tabular}{|c|c|c|c|c|c|c|c|c|c|}
\hline & \multirow[b]{3}{*}{ BUS12 } & \multicolumn{4}{|c|}{ Relative Score (monthly) } & \multicolumn{4}{|c|}{ Mean Response (monthly) } \\
\hline & & BUS12 & $\overline{\text { PEXP }}$ & BEXP & INEXQ1 & $\mathrm{v} 250$ & v252 & $\mathrm{v} 255$ & v256 \\
\hline \multirow{4}{*}{$\begin{array}{l}\text { Relative } \\
\text { Score } \\
\text { (monthly) }\end{array}$} & & 1.00 & & & & & & & \\
\hline & PEXP & 0.78 & 1.00 & & & & & & \\
\hline & BEXP & 0.93 & 0.78 & 1.00 & & & & & \\
\hline & INEXQ1 & 0.74 & 0.73 & 0.72 & 1.00 & & & & \\
\hline \multirow{4}{*}{$\begin{array}{c}\text { Mean } \\
\text { Response } \\
\text { (monthly) }\end{array}$} & V250 & 0.58 & 0.50 & 0.46 & 0.32 & 1.00 & & & \\
\hline & V252 & 0.23 & 0.49 & 0.16 & 0.65 & 0.08 & 1.00 & & \\
\hline & V255 & -0.41 & -0.25 & -0.29 & -0.21 & 0.20 & -0.12 & 1.00 & \\
\hline & V256 & 0.25 & 0.60 & 0.39 & 0.40 & 0.23 & 0.18 & 0.03 & 1.00 \\
\hline
\end{tabular}


Table 3A: Percent Chance of Mutual Fund Investment Increase, by Attributes (V250)

\begin{tabular}{|c|c|c|c|c|c|c|c|c|}
\hline \multirow[b]{2}{*}{ Group } & \multirow[b]{2}{*}{$\frac{\underline{\mathrm{N}}}{\text { (respondents) }}$} & \multirow[b]{2}{*}{$\underline{\text { mean }}$} & \multirow[b]{2}{*}{ std dev } & \multicolumn{3}{|c|}{ Quantiles } & \multicolumn{2}{|c|}{$\mathrm{N}$ (nonrespondents) } \\
\hline & & & & $\underline{0.25}$ & $\underline{0.50}$ & $\underline{0.75}$ & $\begin{array}{l}\underline{\text { Don't }} \\
\text { Know }\end{array}$ & $\begin{array}{c}\text { No } \\
\underline{\text { Response }}\end{array}$ \\
\hline All & 3257 & 42.0 & 28.6 & 20 & 50 & 60 & 219 & 67 \\
\hline Male & 1480 & 45.4 & 29.3 & 20 & 50 & 70 & 63 & 11 \\
\hline Female & 1777 & 39.1 & 27.7 & 20 & 40 & 50 & 156 & 56 \\
\hline Non-Hispanic White & 2633 & 42.5 & 28.5 & 20 & 50 & 60 & 144 & 52 \\
\hline Non-Hispanic Black & 260 & 39.2 & 28.6 & 20 & 40 & 50 & 34 & 9 \\
\hline Hispanic & 183 & 40.9 & 29.7 & 20 & 40 & 60 & 0 & 27 \\
\hline American Indian & 25 & 30.4 & 25.6 & 10 & 20 & 50 & 0 & 0 \\
\hline Asian & 65 & 43.3 & 31.4 & 20 & 40 & 70 & 4 & 1 \\
\hline Married & 1910 & 42.9 & 28.7 & 20 & 50 & 60 & 101 & 21 \\
\hline Divorced & 488 & 40.8 & 29.1 & 17.5 & 40 & 53.5 & 28 & 12 \\
\hline Widowed & 241 & 31.1 & 29.4 & 7.5 & 20 & 50 & 56 & 18 \\
\hline Never Married & 609 & 44.4 & 26.5 & 20 & 50 & 60 & 32 & 15 \\
\hline Age $18-34$ & 808 & 46.3 & 26.1 & 25 & 50 & 60 & 37 & 11 \\
\hline age $35-49$ & 1151 & 43.2 & 27.9 & 20 & 50 & 60 & 46 & 13 \\
\hline age $50-64$ & 788 & 41.1 & 30.4 & 11 & 40 & 60 & 34 & 21 \\
\hline age $65+$ & 510 & 33.5 & 29.4 & 10 & 25 & 50 & 102 & 22 \\
\hline Schooling 0-12 & 1113 & 38.4 & 27.8 & 15 & 40 & 50 & 143 & 31 \\
\hline Schooling 13-15 & 878 & 41.9 & 28.4 & 20 & 50 & 60 & 43 & 18 \\
\hline Schooling 16+ & 1251 & 45.3 & 29.1 & 20 & 50 & 70 & 33 & 18 \\
\hline
\end{tabular}

Note: Each observation arises from a respondent's initial interview only 
Table 3B: Percent Chance of Personal Income Increase, by Attributes (V252)

\begin{tabular}{|c|c|c|c|c|c|c|c|c|c|}
\hline \multirow[b]{2}{*}{ Group } & \multirow[b]{2}{*}{$\frac{\mathrm{N}}{\text { (respondents) }}$} & \multirow[b]{2}{*}{$\underline{\text { mean }}$} & \multirow[b]{2}{*}{$\underline{\text { std dev }}$} & \multicolumn{3}{|c|}{ Quantiles } & \multicolumn{3}{|c|}{$\mathrm{N}$ (nonrespondents) } \\
\hline & & & & $\underline{0.25}$ & $\underline{0.50}$ & $\underline{0.75}$ & $\frac{\text { Don't }}{\text { Know }}$ & $\begin{array}{c}\stackrel{\text { No }}{\text { Response }} \\
\underline{\underline{n}}\end{array}$ & $\frac{\text { Not }}{\text { Applicable }}$ \\
\hline All & 3394 & 50.9 & 37.0 & 10 & 50 & 80 & 95 & 44 & 10 \\
\hline Male & 1507 & 55.7 & 36.2 & 20 & 60 & 90 & 37 & 10 & 0 \\
\hline Female & 1887 & 47.1 & 37.2 & 10 & 50 & 80 & 58 & 34 & 10 \\
\hline Non-Hispanic White & 2736 & 51.4 & 37.5 & 10 & 50 & 85 & 57 & 29 & 7 \\
\hline Non-Hispanic Black & 282 & 52.9 & 34.4 & 20 & 50 & 80 & 12 & 8 & 1 \\
\hline Hispanic & 187 & 41.9 & 32.2 & 10 & 40 & 70 & 21 & 1 & 1 \\
\hline American Indian & 24 & 47.4 & 33.6 & 20 & 50 & 75 & 0 & 1 & 0 \\
\hline Asian & 68 & 52.6 & 37.2 & 10 & 50 & 90 & 1 & 0 & 1 \\
\hline Married & 1969 & 52.2 & 36.7 & 10 & 50 & 83 & 39 & 16 & 8 \\
\hline Divorced & 513 & 50.6 & 36.8 & 10 & 50 & 80 & 10 & 4 & 1 \\
\hline Widowed & 273 & 25.4 & 33.3 & 0 & 10 & 50 & 29 & 13 & 0 \\
\hline Never Married & 630 & 58.4 & 34.9 & 28 & 60 & 90 & 16 & 9 & 1 \\
\hline Age 18-34 & 835 & 62.3 & 33.1 & 40 & 70 & 95 & 15 & 5 & 1 \\
\hline age $35-49$ & 1184 & 57.4 & 35.0 & 20 & 60 & 90 & 13 & 8 & 5 \\
\hline age $50-64$ & 814 & 47.1 & 37.3 & 10 & 50 & 80 & 12 & 14 & 3 \\
\hline age $65+$ & 561 & 26.0 & 33.6 & 0 & 10 & 50 & 55 & 17 & 1 \\
\hline Schooling 0-12 & 1195 & 41.8 & 35.9 & 5 & 40 & 75 & 62 & 24 & 6 \\
\hline Schooling 13-15 & 910 & 51.4 & 37.0 & 10 & 50 & 80 & 15 & 11 & 3 \\
\hline Schooling 16+ & 1273 & 59.3 & 36.1 & 20 & 70 & 90 & 18 & 9 & 1 \\
\hline
\end{tabular}

Note: Each observation arises from a respondent's initial interview only 
Table 3C: Qualitative Expectations for Business Conditions, by Attributes (BEXP)

\begin{tabular}{|c|c|ccccc|}
\hline & & \multicolumn{5}{|c|}{ Response Frequencies (percent of sample) } \\
\cline { 3 - 7 } Group & $\underline{N}$ & $\underline{\text { better }}$ & $\underline{\text { same }}$ & $\underline{\text { worse }}$ & $\underline{\text { DK }}$ & $\underline{\text { NA }}$ \\
All & 3543 & 36.5 & 41.6 & 18.7 & 3.1 & 0.1 \\
& & & & & & \\
Male & 1554 & 44.4 & 36.4 & 16.9 & 2.2 & 0.1 \\
Female & 1989 & 30.3 & 45.7 & 20.1 & 3.8 & 0.2 \\
& & & & & & \\
Non-Hispanic White & 2829 & 37.8 & 41.8 & 17.3 & 3.1 & 0.1 \\
Non-Hispanic Black & 303 & 27.1 & 40.6 & 29.7 & 2.6 & 0.0 \\
Hispanic & 210 & 34.3 & 48.1 & 16.7 & 1.0 & 0.0 \\
American Indian & 25 & 28.0 & 52.0 & 16.0 & 4.0 & 0.0 \\
Asian & 70 & 40.0 & 30.0 & 21.4 & 8.6 & 0.0 \\
& & & & & & \\
Married & 2032 & 38.7 & 41.0 & 17.4 & 2.8 & 0.1 \\
Divorced & 528 & 32.0 & 39.4 & 25.0 & 3.4 & 0.2 \\
Widowed & 315 & 27.0 & 47.9 & 19.7 & 5.4 & 0.0 \\
Never Married & 656 & 38.0 & 42.5 & 16.8 & 2.4 & 0.3 \\
& & & & & & \\
Age 18-34 & 856 & 36.8 & 46.0 & 15.5 & 1.6 & 0.0 \\
age 35-49 & 1210 & 38.4 & 40.9 & 18.0 & 2.4 & 0.3 \\
age 50-64 & 843 & 38.6 & 36.2 & 22.4 & 2.7 & 0.1 \\
age 65+ & 634 & 29.5 & 44.2 & 19.4 & 6.8 & 0.2 \\
& & & & & & \\
Schooling 0-12 & 1287 & 30.1 & 46.9 & 19.6 & 3.3 & 0.2 \\
Schooling 13-15 & 939 & 37.1 & 42.1 & 17.7 & 3.0 & 0.2 \\
Schooling 16+ & 1299 & 42.5 & 36.3 & 18.3 & 2.9 & 0.1 \\
\hline
\end{tabular}

Note: Each observation arises from a respondent's initial interview only 
Table 3D: Qualitative Expectations for Family Income, by Attributes (INEXQ1)

\begin{tabular}{|c|c|ccccc|}
\hline & & \multicolumn{5}{|c|}{ Response Frequencies (percent of sample) } \\
\cline { 3 - 7 } Group & $\underline{N}$ & $\underline{\text { better }}$ & $\underline{\text { same }}$ & $\underline{\text { worse }}$ & $\underline{\text { DK }}$ & $\underline{\text { NA }}$ \\
All & 3543 & 61.2 & 23.0 & 14.9 & 0.9 & 0.1 \\
& & & & & & \\
Male & 1554 & 64.8 & 20.7 & 13.9 & 0.5 & 0.1 \\
Female & 1989 & 58.4 & 24.8 & 15.6 & 1.2 & 0.1 \\
& & & & & & \\
Non-Hispanic White & 2829 & 60.9 & 23.4 & 15.0 & 0.6 & 0.1 \\
Non-Hispanic Black & 303 & 68.3 & 14.9 & 13.5 & 3.0 & 0.3 \\
Hispanic & 210 & 59.5 & 22.9 & 15.7 & 1.9 & 0.0 \\
American Indian & 25 & 44.0 & 44.0 & 12.0 & 0.0 & 0.0 \\
Asian & 70 & 62.9 & 22.9 & 14.3 & 0.0 & 0.0 \\
& & & & & & \\
Married & 2032 & 62.2 & 21.6 & 15.7 & 0.5 & 0.1 \\
Divorced & 528 & 59.1 & 24.1 & 15.2 & 1.5 & 0.2 \\
Widowed & 315 & 38.4 & 41.3 & 18.4 & 1.6 & 0.3 \\
Never Married & 656 & 71.3 & 17.4 & 10.2 & 1.1 & 0.0 \\
& & & & & & \\
Age 18-34 & 856 & 74.7 & 13.9 & & 10.8 & 0.7 \\
age 35-49 & 1210 & 68.8 & 17.5 & 13.2 & 0.3 & 0.2 \\
age 50-64 & 843 & 55.4 & 25.3 & 18.5 & 0.7 & 0.1 \\
age 65+ & 634 & 36.3 & 42.6 & 18.6 & 2.5 & 0.0 \\
& & & & & & \\
Schooling 0-12 & 1287 & 55.1 & 27.7 & 15.8 & 1.4 & 0.1 \\
Schooling 13-15 & 939 & 62.6 & 20.9 & 15.7 & 0.8 & 0.1 \\
Schooling 16+ & 1299 & 66.4 & 19.6 & 13.3 & 0.5 & 0.1 \\
\hline
\end{tabular}

Note: Each observation arises from a respondent's initial interview only 
Table 4: Best Linear Predictors of Probabilistics Expectations, by Attributes and Month

\begin{tabular}{|c|c|c|c|c|}
\hline \multirow[b]{2}{*}{$\underline{\text { Predictor Variable }}$} & \multicolumn{2}{|c|}{$\begin{array}{l}\text { Percent Chance of Mutual } \\
\text { Fund Investment Increase } \\
\text { (V250) }\end{array}$} & \multicolumn{2}{|c|}{$\begin{array}{c}\text { Percent Chance of Personal } \\
\text { Income Increase } \\
\text { (V252) }\end{array}$} \\
\hline & $\underline{\text { coefficient }}$ & $\underline{\text { std err }}$ & $\underline{\text { coefficient }}$ & $\underline{\text { std err }}$ \\
\hline Gender ( $=1$ if male) & 5.58 & $(1.03)$ & 7.19 & $(1.23)$ \\
\hline Non-Hispanic Black & -3.16 & $(1.92)$ & -0.10 & $(2.13)$ \\
\hline Hispanic & -2.93 & $(2.33)$ & -14.08 & $(2.37)$ \\
\hline American Indian & -12.01 & $(5.06)$ & -2.26 & $(5.69)$ \\
\hline Asian & -2.46 & $(4.05)$ & -10.13 & $(4.65)$ \\
\hline Divorced & -0.20 & $(1.51)$ & 0.97 & $(1.82)$ \\
\hline Widowed & -4.59 & $(2.27)$ & -3.82 & $(2.61)$ \\
\hline Never Married & -0.67 & $(1.37)$ & -0.64 & $(1.68)$ \\
\hline Age $35-49$ & -3.42 & $(1.32)$ & -6.09 & $(1.61)$ \\
\hline Age 50-64 & -5.77 & $(1.53)$ & -17.05 & $(1.83)$ \\
\hline Age $65+$ & -10.01 & $(1.95)$ & -35.18 & $(2.25)$ \\
\hline Schooling 13-15 & 2.34 & $(1.28)$ & 6.42 & $(1.54)$ \\
\hline Schooling $16+$ & 5.37 & $(1.20)$ & 13.37 & $(1.43)$ \\
\hline Jul-02 & -6.91 & $(2.41)$ & -1.45 & $(2.90)$ \\
\hline Aug-02 & -5.17 & $(2.39)$ & -0.53 & $(2.92)$ \\
\hline Sep-02 & -8.55 & $(2.36)$ & 2.54 & $(2.93)$ \\
\hline Oct-02 & -7.72 & $(2.36)$ & 0.52 & (2.89) \\
\hline Nov-02 & -2.61 & $(2.46)$ & -0.79 & (2.94) \\
\hline Dec-02 & -5.87 & $(2.44)$ & 1.28 & $(2.93)$ \\
\hline Jan-03 & -4.67 & $(2.47)$ & -2.36 & $(2.97)$ \\
\hline Feb-03 & -8.09 & $(2.34)$ & -4.97 & $(2.84)$ \\
\hline Mar-03 & -3.78 & $(2.44)$ & 1.85 & $(2.83)$ \\
\hline Apr-03 & -6.25 & $(2.52)$ & -4.58 & $(3.06)$ \\
\hline May-03 & -1.58 & $(2.50)$ & -2.72 & $(2.95)$ \\
\hline Intercept & 47.22 & $(2.12)$ & 55.26 & $(2.62)$ \\
\hline $\mathrm{R}^{2}$ & & & & \\
\hline $\mathrm{N}$ & & & & \\
\hline
\end{tabular}

Note: Each observation arises from a respondent's initial interview only 
Table 5: Linear Autoregression of Percent Chance Expectations (6 Month Lag Between Interviews)

\begin{tabular}{|c|c|cc|cc|}
\hline & & \multicolumn{2}{|c|}{ Intercept } & \multicolumn{2}{|c|}{ Slope } \\
\cline { 5 - 6 } Expectation & $\underline{N}$ & coefficient & std err & coefficient & std err \\
Investment Increase (V250) & & & & & \\
Jun-02 to Dec-02 & 187 & 27.84 & $(4.52)$ & 0.39 & $(0.08)$ \\
Jul-02 to Jan-03 & 193 & 25.06 & $(2.99)$ & 0.43 & $(0.06)$ \\
Aug-02 to Feb-03 & 181 & 26.72 & $(3.69)$ & 0.37 & $(0.07)$ \\
Sep-02 to March-03 & 196 & 17.54 & $(2.54)$ & 0.45 & $(0.07)$ \\
Oct-02 to Apr-03 & 182 & 20.96 & $(3.29)$ & 0.54 & $(0.06)$ \\
Nov-02 to May-03 & 191 & 29.50 & $(3.71)$ & 0.35 & $(0.08)$ \\
All & 1130 & 24.14 & $(1.40)$ & 0.43 & $(0.03)$ \\
& & & & & \\
Income Increase (V252) & & & & & \\
Jun-02 to Dec-02 & 203 & 33.05 & $(4.55)$ & 0.43 & $(0.06)$ \\
Jul-02 to Jan-03 & 201 & 19.02 & $(3.43)$ & 0.58 & $(0.06)$ \\
Aug-02 to Feb-03 & 193 & 24.77 & $(4.15)$ & 0.51 & $(0.06)$ \\
Sep-02 to March-03 & 203 & 15.02 & $(3.20)$ & 0.63 & $(0.05)$ \\
Oct-02 to Apr-03 & 192 & 17.79 & $(3.57)$ & 0.63 & $(0.06)$ \\
Nov-02 to May-03 & 193 & 26.06 & $(3.91)$ & 0.38 & $(0.07)$ \\
All & 1185 & 22.61 & $(1.58)$ & 0.53 & $(0.02)$ \\
& & & & & \\
Job Loss (V255) & & & & & \\
Jun-02 to Dec-02 & 142 & 9.23 & $(2.06)$ & 0.52 & $(0.12)$ \\
Jul-02 to Jan-03 & 131 & 12.93 & $(2.47)$ & 0.46 & $(0.12)$ \\
Aug-02 to Feb-03 & 128 & 12.10 & $(2.81)$ & 0.55 & $(0.13)$ \\
Sep-02 to March-03 & 144 & 9.34 & $(1.92)$ & 0.49 & $(0.12)$ \\
Oct-02 to Apr-03 & 121 & 20.44 & $(11.62)$ & 0.22 & $(0.19)$ \\
Nov-02 to May-03 & 118 & 15.06 & $(4.26)$ & 0.70 & $(0.28)$ \\
All & 784 & 12.91 & $(2.02)$ & 0.49 & $(0.07)$ \\
\hline
\end{tabular}




\section{Table 6A: Transition Probabilities for ICS Qualitative Expectations for Business Conditions (BUS12)}

\begin{tabular}{|c|c|c|c|c|}
\hline \multirow{2}{*}{$\begin{array}{c}\text { Initial } \\
\text { Response }\end{array}$} & \multicolumn{4}{|c|}{ Re-Interview Response (6 months later) } \\
\cline { 2 - 5 } good & pro-con & bad & all \\
\hline good & 0.58 & 0.05 & 0.36 & 1.00 \\
pro-con & 0.32 & 0.09 & 0.59 & 1.00 \\
bad & 0.21 & 0.04 & 0.75 & 1.00 \\
\hline
\end{tabular}

Note: Transition probabilities for the 1084 individuals who gave positive (470), neutral (66), or negative (548) responses in the initial interview and such a response in the re-interview.

\section{Table 6B: Transition Probabilities for ICS Qualitative Expectations} for Family Finances (PEXP)

\begin{tabular}{|c|ccc|c|}
\hline \multirow{2}{*}{$\begin{array}{c}\text { Initial } \\
\text { Response }\end{array}$} & \multicolumn{4}{|c|}{ Re-Interview Response (6 months later) } \\
\cline { 2 - 5 } better off & same & worse off & all \\
\hline better off & 0.60 & 0.35 & 0.05 & 1.00 \\
same & 0.26 & 0.65 & 0.09 & 1.00 \\
worse off & 0.16 & 0.47 & 0.37 & 1.00 \\
\hline
\end{tabular}

Note: Transition probabilities for the 1202 individuals who gave positive (469), neutral (598), or negative (135) responses in the initial interview and such a response in the re-interview. 
Figure 1: Chance of Mutual Fund Growth and Closing Value of the S\&P500: June 2002 to May 2003

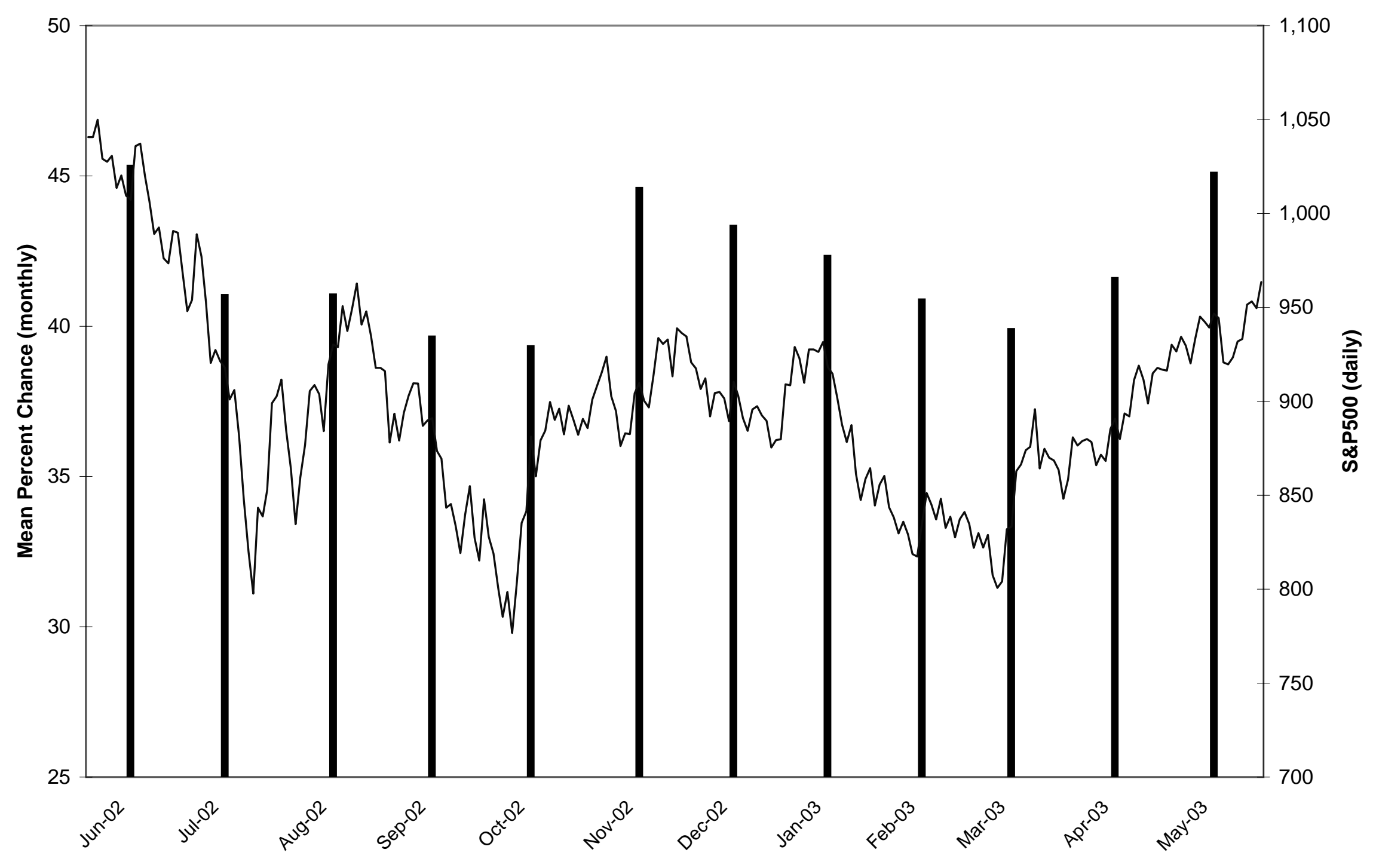

